総合論文

\title{
イリジウム，ロジウム錯体を用いる 触媒的付加環化反応の開発
}

\author{
Iridium and Rhodium Complex-Catalyzed Cycloadditions
}

Takanori Shibata*

Transition metal-catalyzed cycloaddition is an atom-economical and powerful synthetic tool for the construction of cyclic carbon skeletons. Various types of cycloadditions, including [2+2+1], $[2+2+2]$, [4 +2$]$ cycloaddition, etc., have been reported. Their asymmetric versions using chiral transition metal catalysts have also been reported to give enantiomerically-enriched multi-cyclic compounds.

First, an iridium-catalyzed enantioselective Pauson-Khand-type reaction is summarized. Pauson-Khand(-type) reaction is a $[2+2+1]$ cycloaddition of an alkyne, alkene and carbon monoxide, and gives synthetically useful cyclopentenones. Rhodium- and iridium-catalyzed PausonKhand-type reactions using an aldehyde as a $\mathrm{CO}$ source were also mentioned. Second, two types of enantioselective [2+2+2] cycloadditions are described: One is an iridium-catalyzed [2+2+2] cycloaddition of diynes and monoalkynes for the synthesis of chiral teraryls with two axial chiralities. Another is a rhodium-catalyzed [2+2+2] cycloaddition of enynes and monoalkynes for the synthesis of bicyclic cyclohexa-1,3-dienes with a chiral quaternary carbon center. Third, a rhodium-catalyzed enantioselective [2+2] cycloaddition of alkynes and alkenes for the synthesis of chiral cyclobutenes is mentioned.

Key words: cycloaddition, catalysis, iridium, rhodium, chirality, enynes, diynes

\section{はじめに}

付加環化反応とは一般に，複数の反応ユニット間で, 複数の結合生成を伴うことにより環状化合物を与える反 応であり，原料の構成成分がすべて生成物に含まれるた め，原子効率が高い反応である。反応ユニットとして は，アルキン，アルケン，ジエン，アレンなど炭素-炭 素多重結合が多用される。特に，遷移金属錯体を用いる 触媒的付加環化反応は, 中心金属, 配位子の適切な選択 により，比較的穏やかな反応条件下，高い化学選択性， 位置選択性，立体選択性を実現できることから，多環状 化合物合成の強力な合成ツールである1)。反応機構は, 低原子価遷移金属錯体の 2 つの反応ユニットへの酸化的 カップリングによるメタラサイクルの生成に始まり，別 の反応ユニットの挿入などを経て，遷移金属錯体の還元 的脱離により環状化合物が得られるとともに触媒が再生 される。反応部位である不飽和結合の $\pi$ 電子が，遷移

2004 年度有機合成化学奨励賞受賞

* 早稲田大学理工学術院化学科

* Department of Chemistry, Faculty of Science and Engineering, Waseda University
金属錯体へ配位することが起点であるため, ルイス酸触 媒による付加環化反応と異なり，へテロ元素を含んだ官 能基が不要であり，また不斉反応において，高いエナン チオ選択性を実現できる場合が多い。

本総合論文では，筆者の研究グループが開発したイリ ジウム, ロジウム触媒を用いる $[2+2+1],[2+2+2]$, $[2+2]$ 付加環化反応について, 不斉反応を中心に概説 する。

\section{1. $[2+2+1]$ 付加環化反応}

\section{1 触媒的不斉 Pauson-Khand 型反応 ${ }^{2)}$}

アルキン, アルケン, 一酸化炭素の $[2+2+1]$ 付加環 化反応が, 化学量論量の $\mathrm{Co}_{2}(\mathrm{CO})_{8}$ を用いることにより 進行し，シクロペンテノンを与える。この反応が，1973 年にKhand と Pauson により発表され (Pauson-Khand 反応 $)^{3)}$ ，その後，エンインを用いる分子内反応に展開 されたことにより，合成的有用性が飛躍的に高まり，天 然物の全合成における鍵反応として利用された。想定反 応機構からは, 触媒量の $\mathrm{CO}_{2}(\mathrm{CO})_{8}$ により反応が進行し 得ると考えられたが，実際には1994年にJeong が $\mathrm{P}(\mathrm{OPh})_{3}$ を配位子とするCo 錯体により, エンインの触 媒的分子内反応を報告した4)。その後, コバルト錯体以 
外のチタン, ルテニウム，ロジウム錯体を用いることに より次々と触媒的 Pauson-Khand 型反応「本稿では，コ バルト錯体以外を触媒として用いる反応をPausonKhand 型反応(PKR) として区別するつが達成された5)。

一方，不斉 Pauson-Khand 型反応としては，エンイ ンのアルキン，アルケン上，あるいはアルキンとアルケ ンの架橋部にキラル部分をもつ光学活性エンインを用い るジアステレオ選択的反応の報告例があった。さらに， 光学活性なコバルト二核錯体を用いるエナンチオ選択的 反応も報告された。しかしながら，筆者が本研究に着手 した頃, 触媒的かつエナンチオ選択的反応としては, 1996 年にBuchwald により発表された, 光学活性シク ロペンタジエニル配位子をもつキラルチタン錯体を用い る分子内反応が唯一の例であった ${ }^{6)}$ 。本反応は，種々の エンインより対応する光学活性二環性シクロペンテノン を高不斉収率で与える。

そこで筆者は，これまで Pauson-Khand 型反応の触 媒として報告例のないイリジウム錯体を用いて，触媒的 かつエナンチオ選択的反応を試みた。まず予備実験とし て, 酸素架橋型エンイン 1 を用い, Pauson-Khand 型反 応に扮けるイリジウム錯体の触媒活性を検討した。その 結果，一酸化炭素䨌囲気下， $[\mathrm{IrCl}(\operatorname{cod})]_{2}$ のみを触媒と して用いた場合より，配位子として $\mathrm{PPh}_{3}$ を添加した触 媒を用いた場合の方が，反応がより効率的に進行した (式 1)。

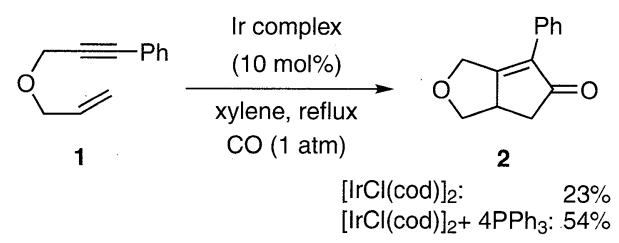

光学活性ホスフィン配位子を用いて, 触媒的不斉 Pauson-Khand 型反応を検討した結果(表 1)，本反応に おいては BINAP が有効であり (entry 1)，特に TolBI$\mathrm{NAP}$ (以降，本稿ではすべて $S$ 体を使用)を用いた場合 に, 対応する光学活性二環性シクロペンテノンが高不斉 収率で得られた (entry 2)。さらに, $2 \mathrm{~mol} \%$ まで[ IrCl(cod) $]_{2}$ を減らしても，長い反応時間を要するが，高収 率かつ高不斉収率を達成できた(entry 3$)$ 。

Table 1 Ir-catalyzed enantioselective PKR.

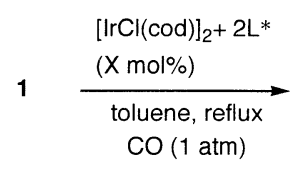

\begin{tabular}{|c|c|c|c|c|c|}
\hline entry & $\mathrm{X} / \mathrm{mol} \%$ & $\mathrm{~L}^{*}$ & time/t & yield $/ \%$ & $\mathrm{ee} / \%$ \\
\hline 1 & 10 & (S)-BINAP & 12 & 64 & 86 \\
\hline 2 & 10 & (S)-ToIBINAP & 18 & 83 & 93 \\
\hline 3 & 2 & (S)-TolBINAP & 72 & 88 & 92 \\
\hline
\end{tabular}

先に述ベたキラルチタン触媒を用いる Pauson-Khand 型反応では, 光学活性シクロペンタジエニル配位子を合 成するために数段階を要する。さらに不斉触媒が金属一 炭素 $\sigma$ 結合を持ち，しかも低原子価チタン錯体である ことから極めて不安定であり，厳密な嫌気，嫌水条件下 で反応を行う必要がある。一方本反応は, 市販かつ空気 中でも秤量可能な $[\mathrm{IrCl}(\operatorname{cod})]_{2}$ と TolBINAPより反応 系中で調製した不斉触媒を用いることにより，高エナン チオ選択的 Pauson-Khand 型反応を実現できる。

そこで，一酸化炭素常圧下，キラルイリジウム触媒に より基質一般性を検討したところ(表 2)，エンインのア ルキン上の置換基としてアリール基(entry 1)，アルキ ル基 (entry 2)，アルキンとアルケンの架橋部に，酸素 原子以外の窒素原子 (entry 3) や炭素原子 (entry 4)をも つエンインの場合も，対応する二環性シクロペンテノン が高不斉収率で得られた。

Table 2 Ir-catalyzed enantioselective PKR of various enynes.

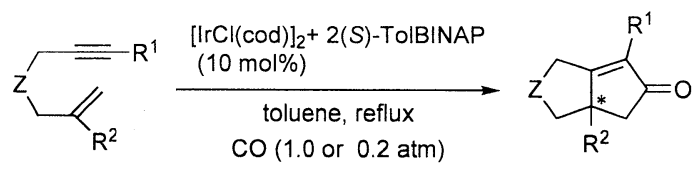

entry

ただし，炭素架橋のエンイン (entry 4) やアルケン上 に置換基をもつエンインの場合(entries 5, 6), 反応の進 行が遅く，未反応のエンインが回収された。そこで，一 酸化炭素低分圧下 (CO: $0.2 \mathrm{~atm}, \mathrm{Ar}: 0.8 \mathrm{~atm})$ で反応を 行ったところ ${ }^{7)}$, エンインの消費が促進され，収率が向 上するだけでなく，不斉収率も上昇した。この結果は， 推定反応機構 $($ スキーム 1)より，次のように説明でき る。すなわち，配位不飽和なキラルイリジウム錯体に対 


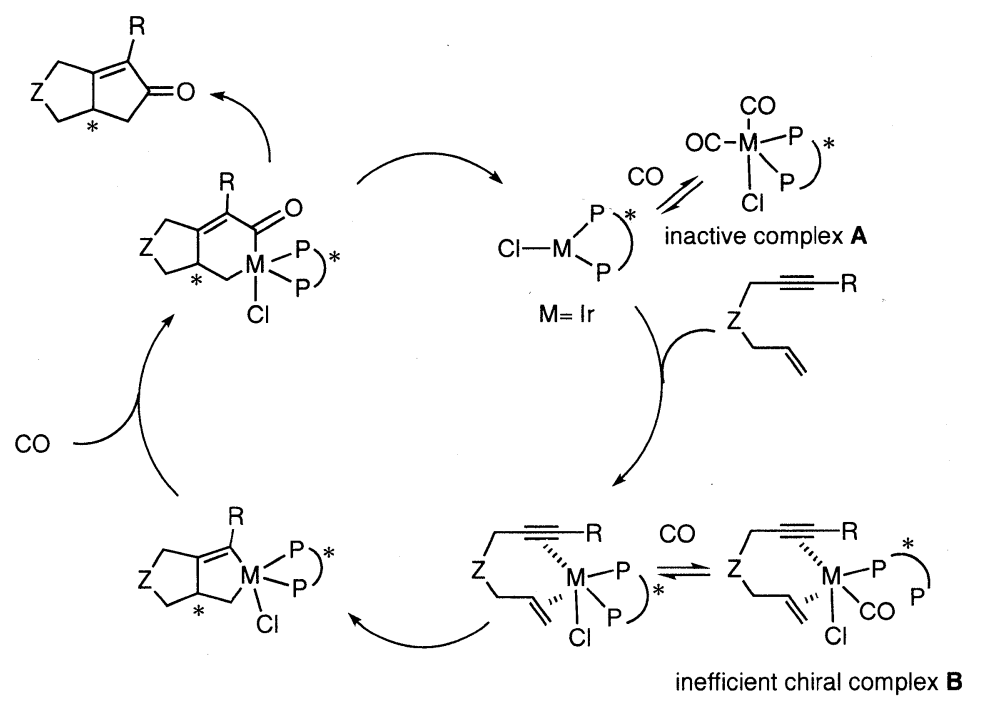

Scheme 1 Explanation for the effect of low partial pressure of $\mathrm{CO}$ gas.

\section{2 アルデヒドを $\mathrm{CO}$ 源として用いる 触媒的 Pauson-Khand 型反応 ${ }^{8)}$}

一酸化炭素分圧を下げることにより, 触 媒効率は上昇する(表 2)が, 一酸化炭素䨌 囲気下で反応を行っている限り, 配位不飽 和なイリジウム錯体への CO の配位によ り, 触媒の不活性化を防ぐことはできな い。そこで, 非一酸化炭素雲囲気下で反応 を行い, カルボニル化の過程で, 必要量の みCO を供給できれば，Pauson-Khand 型 反応の効率が飛躍的に向上すると期待で きる。

そこで筆者は，アルデヒドの脱カルボニ ル化反応を $\mathrm{CO}$ の供給法として考えた。す なわち，ロジウム，イリジウム錯体による
し，エンインが $\pi$ 配位する。その際に，一酸化炭素分 圧が下がると，不活性な配位飽和錯体Aが減少すること により触媒効率が上昇する。また過剩の一酸化炭素によ り，わずかではあるが平衡的に生じると考えられる錯体 B が減少し，エナンチオ選択性が向上すると考えられる。

活性なアルケンであるノルボルネンを用いれば，高エ ナンチオ選択的分子間反応も可能だが，収率を改善する ために，さらなる触媒検討が必要である(式 2)。
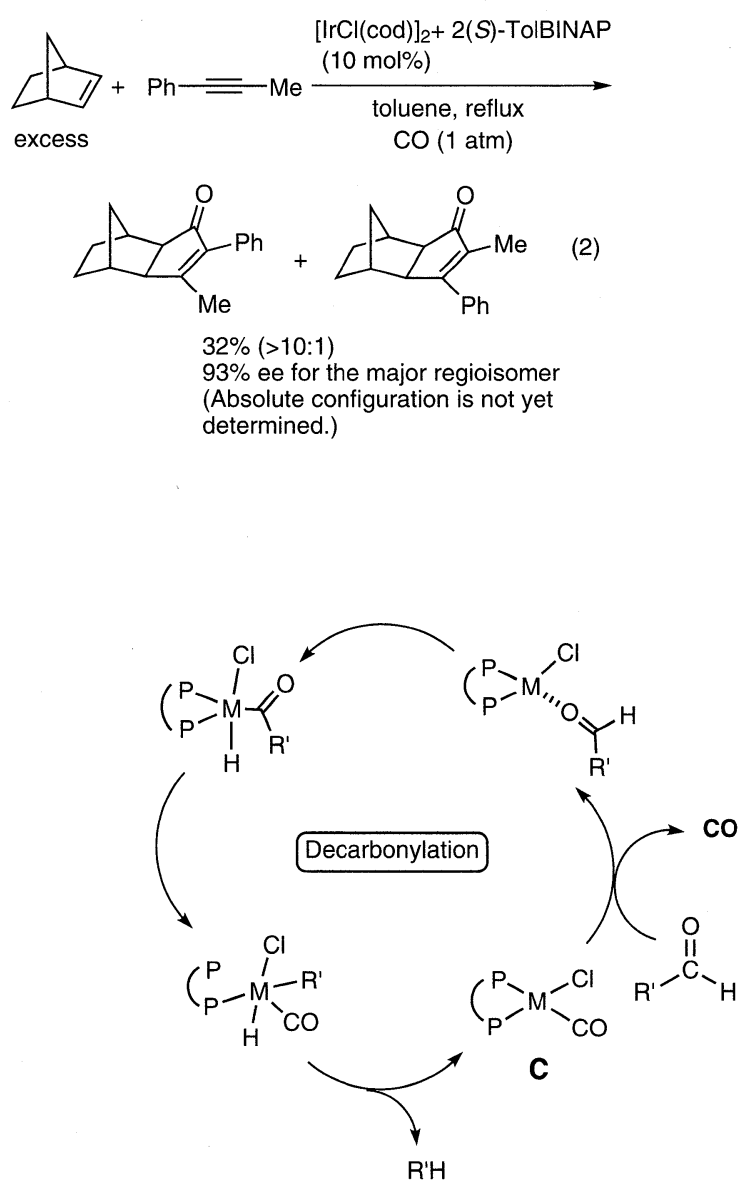

co
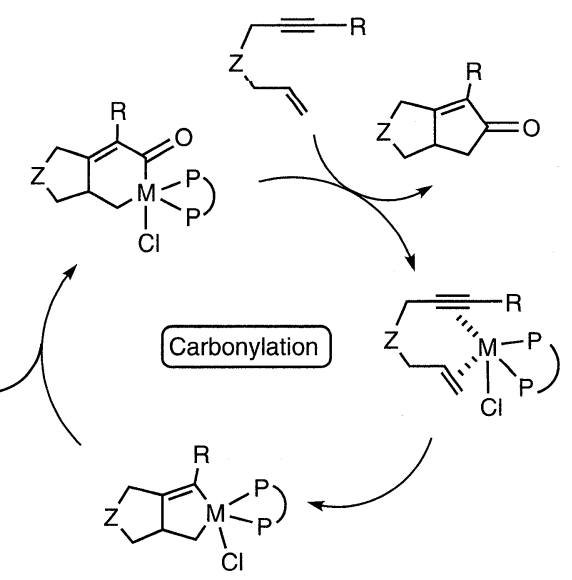
いるので9)，アルデヒド存在下，ロジウム，あるいはイ リジウム触媒を用いるエンインの Pauson-Khand 型反 応を行えば，メタルカルボニル錯体 CがCO の供給源と なり, 結果として, アルデヒドのカルボニル部分を $\mathrm{CO}$ 源とする Pauson-Khand 型反応が可能であると考えた (スキーム 2) ${ }^{10)}$ 。

触媒として $\mathrm{RhCl}(\mathrm{dppp})_{2}$ 〔dppp: 1,3-ビス (ジフェニ ルホスフィノ)プロパン」を用い, 無溶媒条件下, 種々の アルデヒドを用いた結果を表 3 に示す。シンナムアルデ ヒドが極めて有効な $\mathrm{CO}$ 源であり, 反応は 2 時間で終了 し，ほぼ定量的に生成物を与えた(entry 1)。アルデヒ ドを過剩量 (20 equiv.) からほぼ当量 (1.2 equiv.)に減ら しても，高収率を達成できる(entry 1)。また， $\alpha, \beta$-不 飽和アルデヒドが, 飽和アルデヒドより優れた CO 源で あった(entries 3，4)。実際にエンインを添加せずに，

Scheme 2 Proposed scheme of PKR using an aldehyde as a CO source. 
$\mathrm{RhCl}(\mathrm{dppp})_{2}$ 存在下, 触媒的脱カルボニル化反応を行っ たところ, 表中の 4 つのアルデヒドの中でシンナムアル デヒドが，最も速く消費された。

Table 3 Rh-catalyzed PKR using aldehydes as a CO source.

$\begin{array}{cccc}1+\underset{(20 \text { equiv. })}{\mathrm{RCHO}} \begin{array}{c}\text { RhCl(dppp) } \\ (5 \mathrm{~mol} \%)\end{array} & \begin{array}{c}12{ }^{\circ} \mathrm{C} \text {, No solvent } \\ \text { under } \mathrm{Ar}\end{array}\end{array}$

さらに無溶媒条件下, シンナムアルデヒドを $\mathrm{CO}$ 源と する不斉 Pauson-Khand 型反応を試みたところ，[RhCl(cod) $]_{2}$ と TolBINAPより系中で調製する不斉触媒を用 いることにより，高エナンチオ選択的反応を実現した （表 4, entry 1)。本反応をキシレン溶媒中で行うと，工 ンインの消費に長時間を要し，しかも不斉収率は極めて 低かった (entry 2)。また，通常の Pauson-Khand 型反 応と同様に一酸化炭素ガスを $\mathrm{CO}$ 源として用いると, あ る程度不斉収率は改善されるが, 収率が低く、エンイ ンが回収された (entry 3$)$ 。従って, $[\mathrm{RhCl}(\operatorname{cod})]_{2}$ と TolBINAP より調製される中性ロジウム錯体が不斉触媒 として機能するためには，無溶媒条件で，かっアルデヒ ドをCO 源として用いることが重要である。な打本反応 は，表 2 に示した種くのエンインより，高収率，高不育 收率で対応する環化生成物を与えた。

Table 4 Enantioselective PKR using an aldehyde as a $\mathrm{CO}$ source.

$$
\left.1 \underset{[\mathrm{RhCl}(\mathrm{cod})]_{2}+2 \text { TolBINAP }}{(5 \mathrm{~mol} \%)}\right] \underset{120^{\circ} \mathrm{C}, \text { CO source }}{\longrightarrow}
$$

\begin{tabular}{|c|c|c|c|c|c|}
\hline entry & CO source & solvent & time/h & yield $/ \%$ & $\mathrm{ee} / \%$ \\
\hline 1 & cinnamaldehyde & none & 4 & 89 & 82 \\
\hline 2 & cinnamaldehyde & xylene & 36 & 54 & 8 \\
\hline 3 & $\mathrm{CO}$ gas & toluene & 36 & 19 & 70 \\
\hline
\end{tabular}

また，シンナムアルデヒドをCO 源とする不斉 PausonKhand 型反応は, イリジウム錯体でも進行し, ロジウ 厶錯体の場合より高い不斉収率を実現できる。ただし， ロジウム錯体の場合と異なり，溶媒中で反応を行うこと が必要である(式 3)。この結果は，ロジウム錯体は触媒 活性が低いが安定であるため，より過酷な無溶媒条件で 不斉触媒として機能するのに対し，イリジウム錯体は触
媒活性は高いが不安定であるため，溶媒の存在が必要で あると考えると理解できる11)。

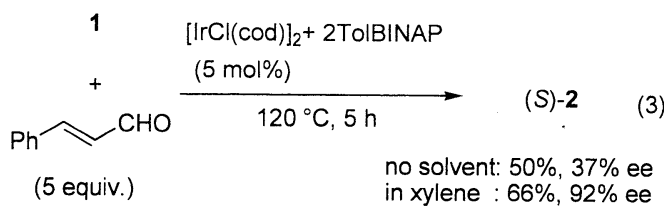

\section{3 アレンインの触媒的 Pauson-Khand 型反応 ${ }^{12)}$}

エンインのアルケン部位をアレンに替えたアレンイン による分子内 Pauson-Khand(型) 反応では，二重結合の 反応部位により，2つの生成物 D, E が考えられる(ス キーム3）。これまでに，筆者が報告した鉄カルボニル 錯体を用いる当量反応 ${ }^{13)}$, 奈良坂, 向, Brummond ら がそれぞれ報告したロジウム錯体による触媒反応 ${ }^{7,14}$ は， いずれも生成物 Dを与えた。生成物 $E$ を選択的に与え る反応としては，モリブデン錯体を用いる反応 ${ }^{15)}$ が知ら れているが，当量反応であるため，生成物 $E$ をえる触 媒反応の検討を行った。

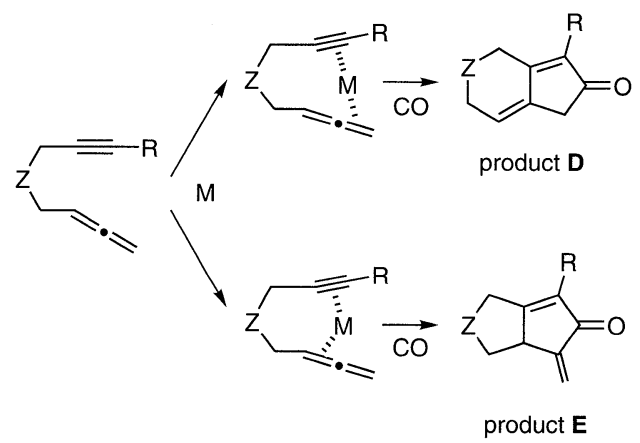

Scheme 3 Two reaction pathways of PKR of allenyne.

その結果，アレン末端にジメチル基を有するアレンイ ンを基質とし，イリジウム触媒 (Vaska 錯体)を用い, 酸化炭素低分圧下 $(\mathrm{CO}: 0.2 \mathrm{~atm}, \mathrm{Ar}: 0.8 \mathrm{~atm})$ で反応を行 うことにより，選択的にアルキリデン基をもつシクロペ ンテノンを与えた (式 4)。なお，イリジウム錯体に替 え, 対応するロジウム錯体 $\left[\mathrm{RhCl}(\mathrm{CO})\left(\mathrm{PPh}_{3}\right)_{2}\right]$ を用いる と, アレンの外側で反応した後， $\beta$-水素脱離が進行し た交差共役型トリエンが生成する ${ }^{16)}$ 。

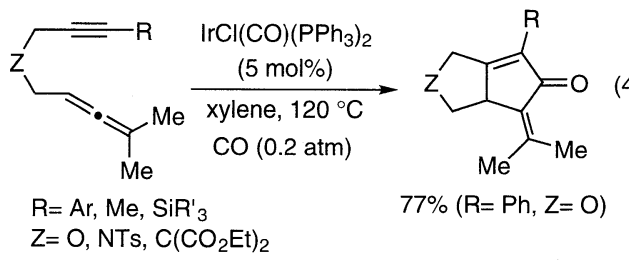

生成物 $\mathrm{E}$ をえる反応は，不斉反応への展開も可能で ある。収率は低いが，カチオン性イリジウム錯体を用い ることにより，初めてのアレンインのエナンチオ選択的 Pauson-Khand 型反応を達成した $\left(\right.$ 式 5 ${ }^{17)}$ 。 


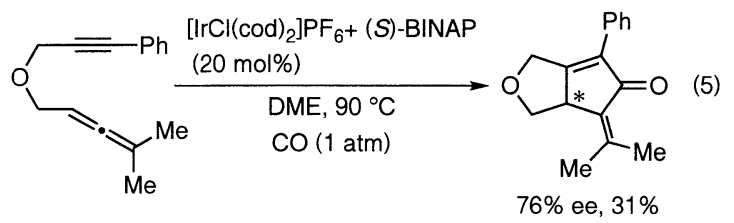

\section{4 ジインを用いるシクロペンタジエノン合成 ${ }^{18}$}

エンインに替え，ジインを用い，一酸化炭素䨌囲気下 $[2+2+1]$ 付加環化反応を行うと, 活性なジエンとして 合成化学上有用なシクロペンタジエノンが得られる。し かしながら，シクロペンタジエノンは反芳香族性 $4 \pi$ 系 の極限構造を持つため不安定であり，その沉用な触媒的 合成法はほとんど報告されていなかった。一方筆者は, かさ高いトリアルキルシリル基を有するアルキンを用い ることにより，当量のコバルトカルボニル錯体を用いる 2 分子のアルキン，またはジインと一酸化炭素の $[2+2+1]$ 付加環化反応を報告した ${ }^{19)}$ 。そこで触媒反応への展開を 検討したところ，イリジウム錯体が高い触媒活性をもつ ことを見出した。本反応は，対称ジインより種々の対称 二環性シクロペンタジエノンを与える(式 6)。

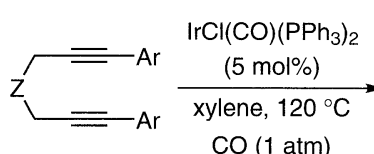

$\mathrm{Z}=\mathrm{O}, \mathrm{CH}_{2}, \mathrm{C}\left(\mathrm{CO}_{2} \mathrm{R}^{\prime}\right)_{2}$

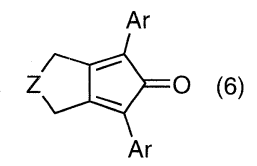

$86 \%$
$\left(\mathrm{Ar}=\mathrm{Ph}, \mathrm{Z}=\mathrm{C}\left(\mathrm{CO}_{2} \mathrm{Bn}\right)_{2}\right)$

さらに，イソシアニドとジインとの $[2+2+1]$ 付加環 化反応によるイミノシクロペンタジエンの触媒的合成を 検討した。イソシアニドは一酸化炭素と等電子構造を持 つが，金属への配位能が高いため，イソシアニドの挿入 を伴う触媒的付加環化反応の報告例がほとんどなかっ た。実際に，上記の一酸化炭素插入反応で有効だった Vaska 錯体を用いても， $[2+2+1]$ 付加環化反応は全く進 行しなかった。金属触媒，反応条件を精査した結果， $\lfloor\mathrm{RhCl}(\mathrm{cod})\rfloor_{2}$ を用い，イソシアニド 0.2 当量を 5 回に 分けて 15 分扮きに添加することにより，筆者が知る限 り初めてのイソシアニドの挿入を伴う触媒的 $[2+2+1]$ 付加環化反応を達成した(式 7)。

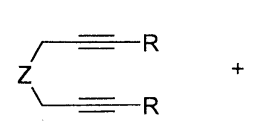

$\mathrm{R}=\mathrm{Ph}, \mathrm{Me}, \mathrm{TMS}$ $\mathrm{Z}=\mathrm{C}\left(\mathrm{CO}_{2} \mathrm{R}^{\prime}\right)_{2}, \mathrm{O}, \mathrm{CH}_{2}$

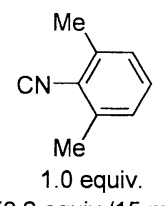

( 0.2 equiv. $/ 15 \mathrm{~min})$

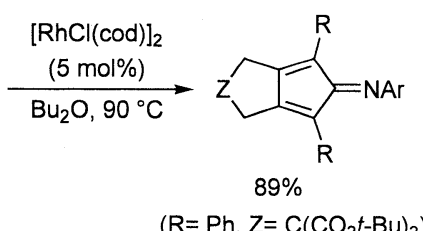

\section{2. 不斉 $[2+2+2]$ 付加環化反応}

$[2+2+2]$ 付加環化反応，特にアルキンの三量化によ るベンゼン誘導体の合成反応は, 有機合成上有用な反応 である。1948 年に Reppe が，ニッケル錯体存在下，ア セチレンの反応においてベンゼンの生成を確認し20), 1967 年に山崎が報告したコバルト錯体によるジフェニ ルアセチレンの三量化反応により，有機合成への利用の 道が開かれた21)。その後, Vollhardtにより $\mathrm{CpCo}(\mathrm{CO})_{2}$ を用いる反応が包括的に研究され，特にジインとアルキ ンとの半分子内 (semi-intramolecular) [2+2+2]付加環 化反応が天然物合成へ利用されたことにより，その合成 的有用性は飛躍的に増大した ${ }^{22)}$ 。そして, ロジウム， ニッケル，パラジウム錯体など種々の遷移金属錯体が触 媒として機能することが報告された ${ }^{1 \mathrm{~d}, \mathrm{e})}$ 。さらに最近で は，アルキンだけでなく，アルケンを含んだ三量化反応 も報告されている。

筆者は，末端にアリール基を有するジインと二置換ア ルキンとの $[2+2+2]$ 付加環化反応により，軸不斉を有 するビアリール骨格の合成を行った。また，アルケン上 に置換基をもつエンインと，アルキンとの $[2+2+2]$ 付 加環化反応により，縮環部に不斉四級炭素をもつ二環性 化合物の合成を行った (スキーム 4)。

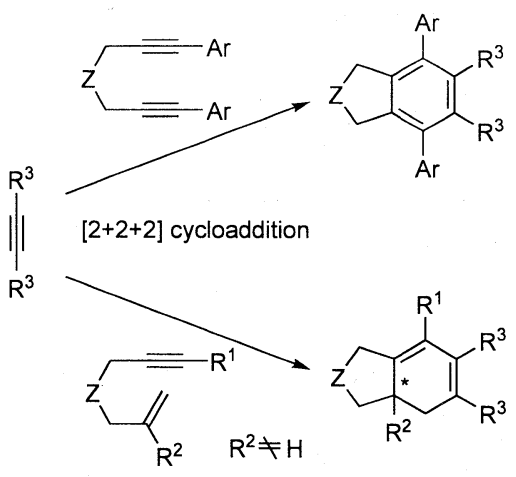

Scheme $4 \quad[2+2+2]$ Cycloaddition for the generation of chirality.

\section{1 軸不斉ビアリール骨格の構築 ${ }^{23}$}

これまで，アルキンの触媒的 $[2+2+2]$ 付加環化反応 は数多く報告されているが，不斉 $[2+2+2]$ 付加環化反 応は，筆者が知る限り 2 例のみであった。森は，キラル なニッケル触媒を用いたトリインとアセチレンとのエナ ンチオトピックなグループ区別反応により，ベンジル位 に不斉炭素原子をもつベンゼン誘導体を合成している 24)。一方 Stará は，キラルなニッケル触媒を用いたトリ インの分子内反応により，らせん不斉を有するへリセン 誘導体を得ているが，中程度の不斉収率である上，反応 例も少ない25)。

そこで筆者は, 新規な不斉 $[2+2+2]$ 付加環化反応と して，オルト置換アリール基を末端にもつジインと，二 
置換モノアルキンとの反応を着想した。環化生成物であ るテルアリール化合物に扔けるアリール間の 2 つの単結 合は，オルト位の置換基，ジインの架橋部に由来する環 構造により, 自由回転が阻害され，2つの軸不斉が生ず ると考えられる $(\text { スキーム } 5)^{26,27) 。 ~}$

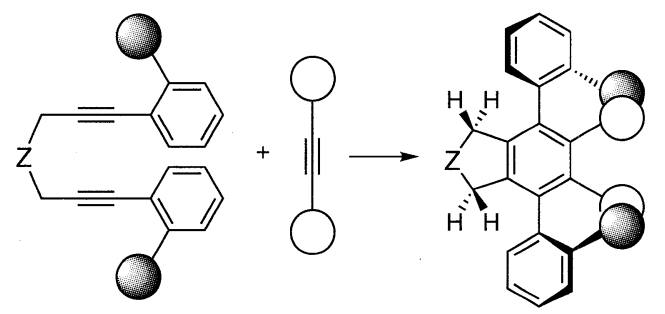

Scheme $5[2+2+2]$ Cycloaddition for the generation of two axial chiralities.

まず，両末端にナフチル基をもつジプロパルギルエー テルと1,4-ジメトキシー2-ブチンをそれぞれジイン，モ ノアルキンとして用い, $[\operatorname{IrCl}(\mathrm{cod})]_{2}$ と種々の光学活性 二座リン配位子より系中で調製した不斉触媒によるエナ ンチオ選択的 $[2+2+2]$ 付加環化反応を検討した。その 結果, 本反応に扔いて MeDUPHOS [1,2-(ビス-2, 5-ジ メチルホスホラノ)ベンゼン, 以降すべて $(S, S)$ 体を使 用了が極めて有効な不斉配位子であり, meso 体の生成 が $400 \mathrm{MHz}{ }^{1} \mathrm{H}$ NMR で確認できず, $d l$ 体の鏡像体過剩 率は 99\%以上であった(式 8)。
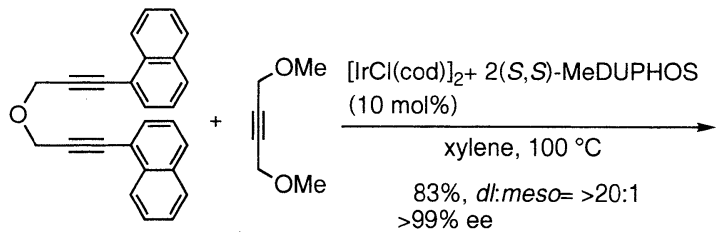

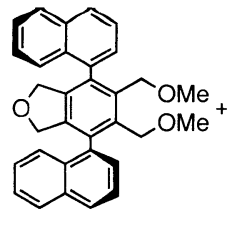

$d l$ isomer

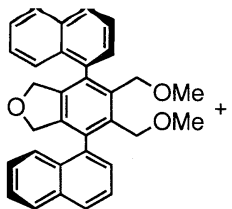

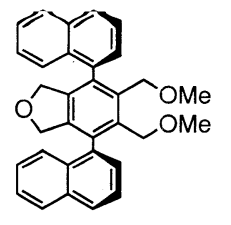

meso isomer
$[\mathrm{IrCl}(\mathrm{cod})]_{2}$ と MeDUPHOS より反応系中で調製する 不斉触媒 (以後 Ir-MeDUPHOS cat.と表記)を用いるこ とで, $[2+2+2]$ 付加環化反応が高ジアステレオ, かつ 高エナンチオ選択的に進行し, 種々のオルト置換アリー ル基を両末端に有するジイン (entries 1-3), 窒素原子 や炭素原子を架橋部にもつジイン (entries 4-6)より， 対応する $C_{2}$ 対称をもつ軸不斉テルアリール化合物が得 られる(表5)。

さらに，is-オレフィン部分により架橋されたジイン も同条件下で反応し, DDQ 酸化による芳香化を経て, 高不斉収率でテルナフタレン化合物を与える(式 9)。
Table 5 Enantioselective $[2+2+2]$ cycloaddition of various diynes.

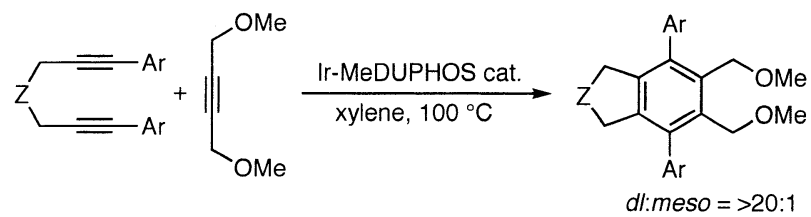

\begin{tabular}{ccccc}
\hline entry & $\mathrm{Z}$ & $\mathrm{Ar}$ & yield/\% & ee/\% \\
\hline 1 & $\mathrm{O}$ & 4-MeO-1-Naphthyl & 72 & 99 \\
2 & $\mathrm{O}$ & 2-MePh & 85 & 99 \\
3 & $\mathrm{O}$ & 2-ClPh & 85 & 98 \\
4 & $\mathrm{NTs}$ & 1-Naphthyl & 92 & 99 \\
5 & $\mathrm{C}\left(\mathrm{CO}_{2} \mathrm{Et}\right)_{2}$ & 1-Naphthyl & 77 & $>99$ \\
6 & $\mathrm{CH}_{2}$ & 1-Naphthyl & 96 & $>99$ \\
\hline
\end{tabular}

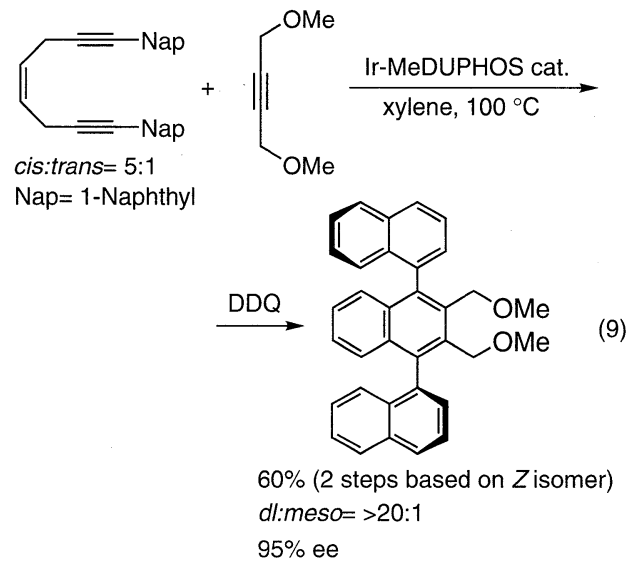

\section{2 連続する軸不斉によるらせん化合物の合成 ${ }^{28)}$}

次に本反応の展開として, ジイン部位を複数もつポリ インを原料とする連続的不斉 $[2+2+2]$ 付加環化反応を 検討した。その結果，これまでと同じキラルイリジウム 触媒を用いると，ナフタレン環をスペーサーとするテト ライン 3 と, モノアルキンとの反応がほぼ完全にエナン チ才選択的に進行し，4つの軸不斉をもつ光学活性キン クアリール化合物が収率よく得られた（式 10）。モノア ルキンとしてジオールを用いても, 溶解性の高い DME （1,2-ジメトキシエタン)を溶媒に用いることにより，高 いエナンチオ選択性を実現できる。

ジインの場合と同様に，cis-オレフィンにより架橋さ れたテトラインも反応し, 引き続く芳香化により, 光学 活性キンクナフタレン化合物を与える(スキーム 6)。メ トキシ基をブロモ基に変換することにより, 単結晶構造 解析が可能となり, 軸不斉に由来し，5つのナフタレン 環がらせん状に配置していることを確認できた。

さらに4つのジイン部位をもつオクタインを用いて， 不斉 $[2+2+2]$ 付加環化反応を行ったところ，8つの連続 する軸不斉が完全に制御され，ほぼ一方の鏡像異性体の みが，高収率で得られた(式 11)。

また，1，3，5-トリエチニルベンゼンを中心骨格にもつ 

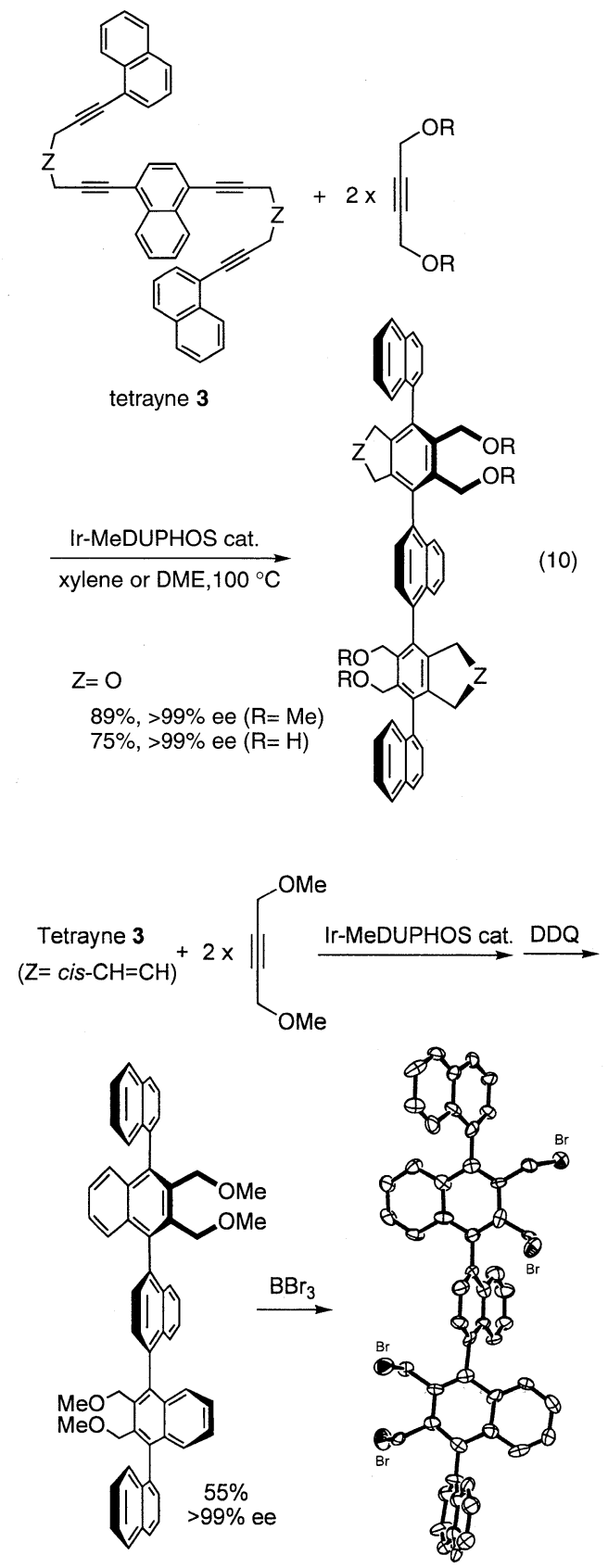

Scheme 6 Helical chirality based on consecutive axial chiralities.

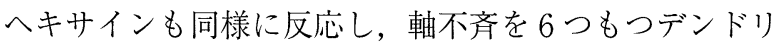
マー型キラル化合物が，ほぼ一方の鏡像異性体のみ得ら れた (式 12) $)^{29)}$ 。

\section{3 軸不斉オルトジアリールベンゼン誘導体の合成 ${ }^{30)}$}

次に，トリインの分子内反応において，不斉 $[2+2+2]$ 付加環化反応を試みたところ，この場合も Ir-MeDUPHOS 錯体が有効な不斉触媒として機能した。例えば，トリイ ンの両末端にナフチル基をもち，酸素原子により架橋さ れたトリインの場合 $(\mathrm{Ar}=1-\mathrm{Naphthyl}, \mathrm{Z}=\mathrm{O})$, 高不斉 収率で対応する環化体を与えた (スキーム 7)。両末端の 置換基を種々のアリール基に替えることにより，オルト 位に連続した軸不斉をもつオルトジアリールベンゼン誘

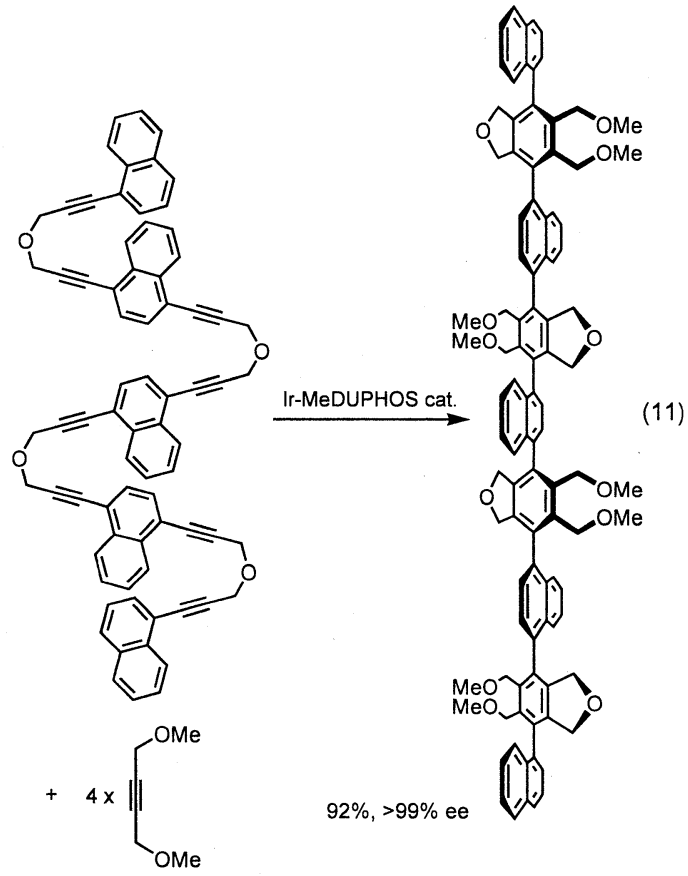

導体が高エナンチオ選択的に得られる。

\section{$2.4[2+2+2]$ 付加環化反応による不斉四級炭素の}

構築 ${ }^{31)}$

次に筆者は，1,6-ジインに替え，1,6-エンインとの反 応を行った。アルケン部位に置換基を有するエンインと アルキンとの間で，不斉 $[2+2+2]$ 付加環化反応が進行 することにより，縮環部に不斉四級炭素をもつ二環性シ クロヘキサ-1,3-ジエンが得られる。反応条件を検討し た結果，本反応においては，力チオン性ロジウム錯体が 極めて活性であった。TolBINAP を不斉配位子としても つ触媒を用いることにより，付加環化反応は高エナンチ 才選択的に進行した(スキーム 8)。本反応は, エンイン のアルキン末端の置換基 $\left(\mathrm{R}^{1}\right)$ ，アルケン上の置換基 $\left(\mathrm{R}^{2}\right)$ ，架橋部 $(Z)$ について広い一般性を有し，対応する 二環性シクロヘキサ-1,3-ジエシが, 高鏡像体過剩率で 得られた ${ }^{32)}$ 。

さらにアルキンとして，アセチレンガスを利用するこ とも可能である(式 13)。アセチレン分圧を下げること により，アセチレンとエンインのアルキン部分の $2: 1$ 環化体であるべンゼン誘導体の副生をある程度抑えら れ，収率が向上する。

また, 非対称なアルキンとのカップリング反応も進行 する。アルキンの位置選択性は極めて高いとは言えない が, いずれの環化体も, 高不斉収率で得られた(式 14)。

不斉四級炭素の効率的合成法の開発は, 有機合成化学 に拈いて重要なテーマの1つであり，これまでに， Diels-Alder 反応，溝呂木-Heck 反応，アルキル化反応 など種々の触媒的かつ高エナンチオ選択的な手法が報告 されている。上記したエンインとアルキンの不斉 $[2+2+2]$ 付加環化反応は, 不斉四級炭素構築の新規な 


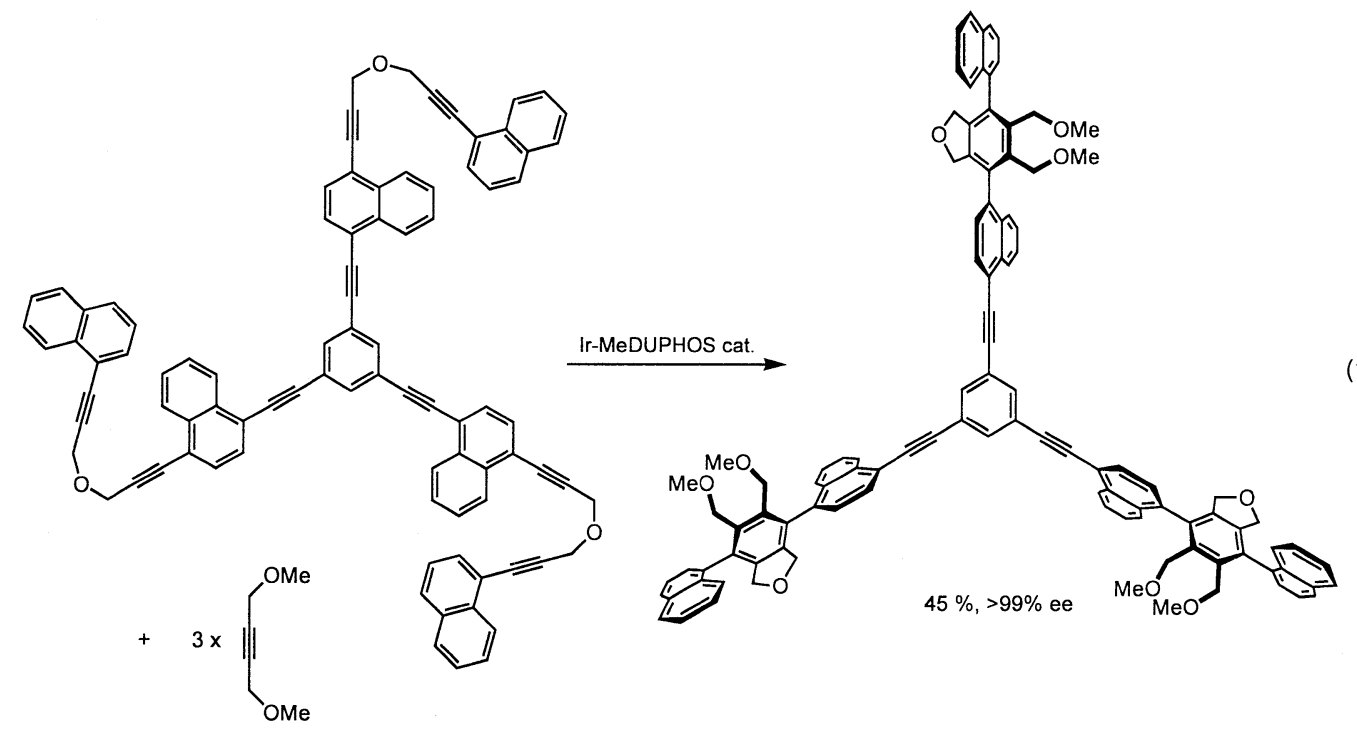

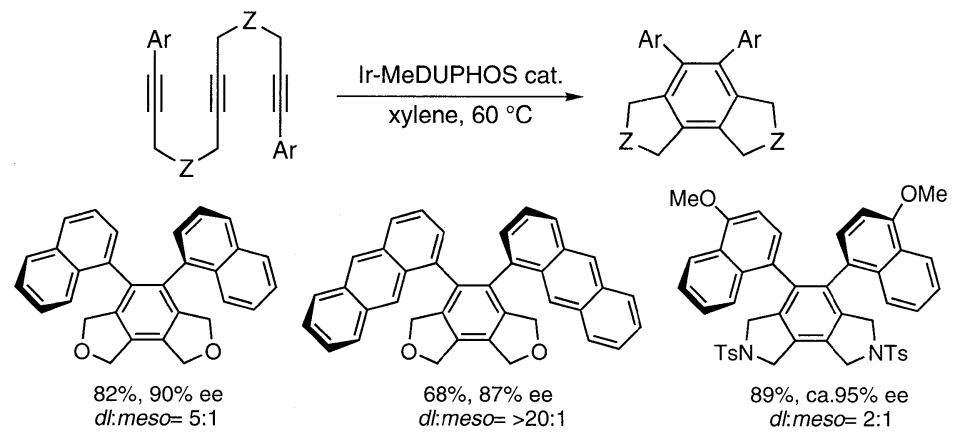

Scheme 7 Intramolecular $[2+2+2]$ cycloaddition of triynes.

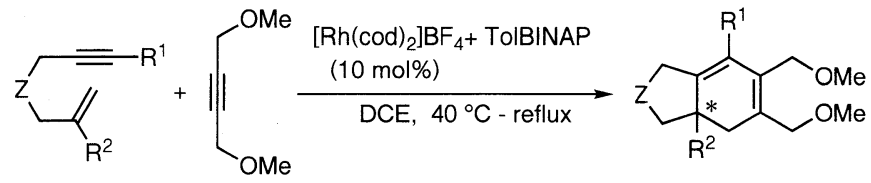

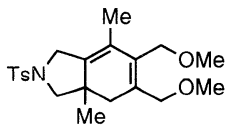

$81 \%, 97 \%$ ee

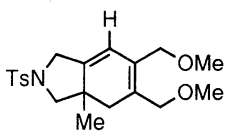

$72 \%, 98 \%$ ee

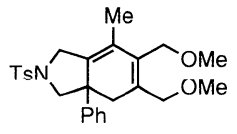

$61 \%, 89 \%$ ee

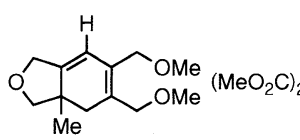

$65 \%, 97 \%$ ee

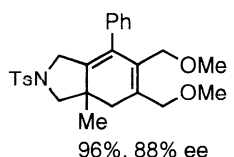

$96 \%, 88 \%$ ee

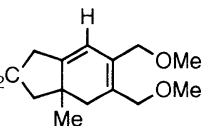

$60 \%, 92 \%$ ee
Scheme $8 \quad[2+2+2]$ cycloaddition for the generation of a quaternary carbon center.

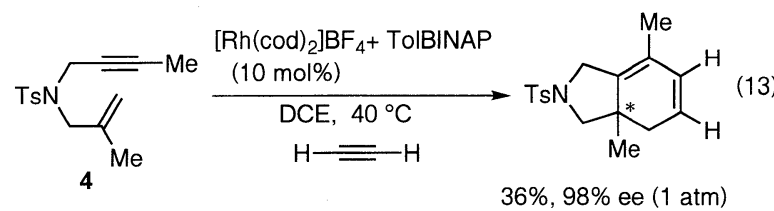

$36 \%, 98 \%$ ee $(1 \mathrm{~atm})$ $67 \%, 99 \%$ ee $(0.2 \mathrm{~atm})$

アプローチと言える。

\section{3. 不斉 $[2+2]$ 付加環化反応 33}

$[2+2]$ 付加環化反応は, 4 員環骨格を構築する最も直 接的な合成手法である。しかしながら， [2+2+1]，
$[2+2+2] ，[4+2]$ 付加環化反応の報告例と比 較すると，遷移金属錯体を用いる触媒的 $[2+2]$ 付加環化反応の例は少ない。アルキン とアルケンとのカップリングによるシクロ ブテン骨格形成反応としては，ニッケル， ルテニウム触媒を用いる例が報告されてい るが，光学活性シクロブテンを与える不斉 $[2+2]$ 付加環化反応は，キラルなアルキンを 用いるジアステレオ選択的反応のみであ る34)。そこで筆者は，活性なアルケンであ るノルボルネンを用いてアルキンとの分子 間 $[2+2]$ 付加環化反応を検討した結果，キラ ルなカチオン性ロジウム触媒を用いること により，高エナンチオ選択的 [2+2]付加環化 反応を達成した。

アルキン上にエステル基を持つフェニル 置換プロピオン酸メチルエステルとノルボ ルネンとの反応では， $\mathrm{Rh}-\mathrm{H}_{8}-\mathrm{BINAP}$ 触媒を 用いることにより，シクロブテンが高不斉 収率で得られた（表 6, entry 1)。ベンゼン環 上に電子供与性基を導入すると，エナンチ 才選択性が向上する(entries 2,3)。なお， アルキニルケトンの場合, 収率は高いが, 不斉収率が極めて低い(entry 4)。一方，力 ルボニル基を持たないエーテルの場合，収 率は低いが，アルキニルケトンの場合より 不斉收率は若干向上する (entry 5)。以上の 結果は, 本反応において, 高収率, 高エナンチ才選択性 を実現するためには，アルキンの一方に電子供与性基 が，もう一方に電子吸引性基としてエステル基を有する ことが重要であると言える。

実際に, 電子供与能が大きいメチル基を持つ 2-ブチ 


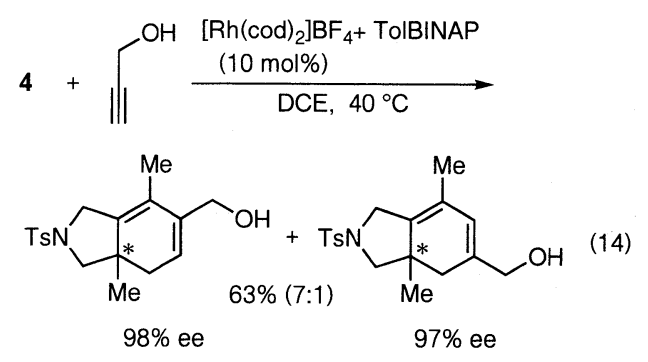

Table 6 Enantioselective $[2+2]$ cycloaddition of norbornene and alkynes.

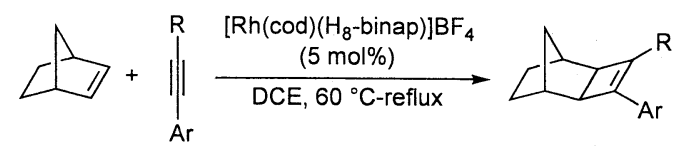

\begin{tabular}{ccccc}
\hline entry & $\mathrm{R}$ & $\mathrm{Ar}$ & yield $\%$ & $\mathrm{ee} / \%$ \\
\hline 1 & $\mathrm{CO}_{2} \mathrm{Me}$ & $\mathrm{Ph}$ & 85 & 80 \\
2 & $\mathrm{CO}_{2} \mathrm{Me}$ & $4-\mathrm{MeOPh}$ & 98 & 90 \\
3 & $\mathrm{CO}_{2} \mathrm{Me}$ & $4-\mathrm{MePh}$ & 97 & 86 \\
4 & $\mathrm{C}(\mathrm{O}) \mathrm{Me}^{\mathrm{a}}$ & $\mathrm{Ph}$ & 94 & 14 \\
5 & $\mathrm{CH}_{2} \mathrm{OMe}^{\mathrm{a}}$ & $\mathrm{Ph}$ & 59 & 26 \\
\hline
\end{tabular}

${ }^{a}$ The chiral catalyst was in situ prepared from $\left[\mathrm{Rh}(\mathrm{cod})_{2}\right] \mathrm{BF}_{4}$ and $\mathrm{H}_{8}$-BINAP.
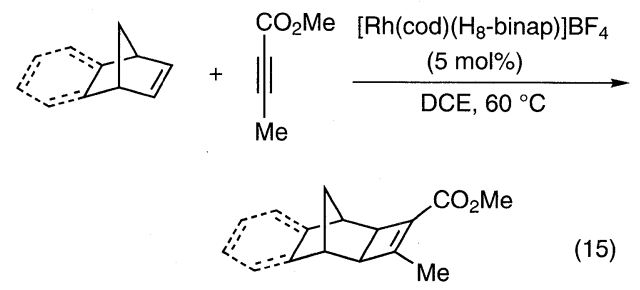

$55 \%, 99 \%$ ee (norbornene) $68 \%, 94 \%$ ee (benzonorbornadiene)

ン酸メチルエステルを用いた場合，エナンチオ選択性は さらに向上し，ノルボルネンあるいはベンゾノルボルナ ジエンとの反応で，対応する多環性シクロブテンが高不 斉収率で得られた(式 15)。

これまで，アルキンとアルケンとのエナンチオ選択的 $[2+2]$ 付加環化反応としては，キラルルイス酸触媒を用 いる反応》゙報告されている り初めての遷移金属触媒を用いるエナンチ才選択的反応 と位置付けられる。

\section{おわりに}

イリジウム，あるいはロジウム錯体を用いることによ り，種々の形式の不斉付加環化反応が進行し，多彩な多 環状化合物を与えることを見出した。エンイン，一酸化 炭素による不斉 $[2+2+1]$ 付加環化反応では，キラルイ リジウム錯体を不斉触媒として用いることにより，高エ ナンチオ選択性を実現し, 合成上有用な光学活性二環性 シクロペンテノンを得た。反応性にそしいエンインの場 合，一酸化炭素分圧を低下させることにより，収率なら びに不斉収率の改善を行った。さらに，CO 源としてア
ルデヒドを用いることにより，有毒性の一酸化炭素ガス の使用が避けられるだけでなく，より効率的な $\mathrm{CO}$ の挿 入を伴う触媒系を構築できた。また，ジインとアルキン との $[2+2+2]$ 付加環化反応では, ベンゼン環の構築を 伴って，極めて高エナンチ才選択的な軸不斉誘起を達成 できた。一方エンインとアルキンとの $[2+2+2]$ 付加環 化反応では，効率的な不斉四級炭素の構築が可能であ り，不斉反応における新たな合成ツールとしての $[2+2+2]$ 付加環化反応を提案できた。誌面の都合上割 愛したが，イリジウム触媒を用いた不斉 $[4+2]$ 付加環化 反応 ${ }^{36)}$, エン型反応 ${ }^{37)}$, 環化異性化反応による光学活性 三員環合成法 ${ }^{38)}$ も開発した。

反応条件を検討する中で，イリジウム，ロジウム錯体 のいずれか一方のみで進行する反応，あるいは(不斉)配 位子は異なるが，いずれでも進行する反応がある。今 後，それぞれの触媒の特性を活かし，新反応，あるいは これまで合成に多段階を要したり，高エナンチオ選択的 供給法が報告されていない炭素骨格のより簡便な構築法 の開発を目指す。

謝 辞 ご指導, ご鞭撻を賜つた岡山大学理学部・高木 謙太郎教授に感謝申し上げます。本研究はすべて，岡山 大学理学部化学科機能化学研究室, 早稲田大学理工学部 化学科柴田研究室の学生諸氏の日々たゆま努力の賜物 であり，深く感謝します。なお本研究の一部は，文部科 学省科学研究費補助金，住友財団，長瀬科学技術振興財 団，稲盛財団，三菱化学研究奨励基金によるものであ り，深謝いたします。

(2006 年 4 月 21 日受理)

\section{文 献}

1) (a) M. Lautens, W. Klute, W. Tam, Chem. Rev., 96, 49 (1996); (b) I. Ojima, M. Tzamarioudaki, Z. Li, R. J. Donovan, ibid., 96, 635 (1996); (c) B. M. Trost, Acc. Chem. Res., 35, 695 (2002); (d) C. Aubert, O. Buisine, M. Malacria, Chem. Rev., 102, 813 (2002): (e) T. Nakamura, Y. Yamamoto, ibid., 104, 2127 (2001)

2) (a) T. Shibata, K. Takagi, J. Am. Chem. Soc., 122, 9852 (2000); (b) T. Shibata, N. Toshida, M. Yamasaki, S. Maekawa, K. Takagi, Tetrahedron, 61, 9974 (2005)

3) I. U. Khand, G. R. Knox, P. L. Pauson, W. E. Watts, J. Chem. Soc., Perkin Trans. 1, 1973, 977

4) N. Jeong, S. H. Hwang, Y. Lee, Y. K. Chung, J. Am. Chem. Soc., 116, 3159 (1994)

5）最近の Pauson-Khand(型)反応に関する総説: (a) B. E. Hanson, Comments on Inorg. Chem., 23, 289 (2002); (b) 柴田高 範，有合化, 61, 834, (2003); (c) S. E. Gibson, A. Stevenazzi, Angew. Chem. Int. Ed., 42, 1800 (2003); (d) D. Struebing, M. Beller, "Transition Metals for Organic Synthesis (2 nd Ed.)" ed. by M. Beller, C. Bolm, Wiley-VCH Verlag, Weinheim, 2004, Vol. 1, p 619

6) F. A. Hicks, S. L. Buchwald, J. Am. Chem. Soc., 118, 11688 (1996)

7) T. Kobayashi, Y. Koga, K. Narasaka, J. Organomet. Chem., $624,73(2001)$

8) (a) T. Shibata, N. Toshida, K. Takagi, Org. Lett., 4, 1619 
(2002); (b) idem, J. Org. Chem., 68, 7446 (2002)

9) (a) J. Blum, E. Oppenheimer, E. D. Bergmann, J. Am. Chem. Soc., 89, 2338 (1967); (b) K. Ohno, J. Tsuji, ibid., 90, 99 (1968)

10）ペンタフルオロベンズアルデヒドさらにはホルムアルデヒド をCO 源とする Pauson-Khand 型反応が報告されている。(a) T. Morimoto, K. Fuji, K. Tsutsumi, K. Kakiuchi, J. Am. Chem. Soc., 124, 3806 (2002); (b) T. Morimoto, K. Fuji, K. Kakiuchi, Angew. Chem. Int. Ed., 42, 2409 (2003)

11) N. Jeong, B. K. Sung, Y. K. Choi, J. Am. Chem. Soc., 122, 6771 (2000)

12) T. Shibata, S. Kadowaki, M. Hirase, K. Takagi, Synlett, 2003, 573

13) (a) K. Narasaka, T. Shibata, Chem. Lett., 1994, 315; (b) T. Shibata, Y. Koga, K. Narasaka, Bull. Chem. Soc. Jpn., 68, 911 (1995)

14) (a) C. Mukai, I. Nomura, K. Yamanishi, M. Hanaoka, Org. Lett., 4, 1755 (2002); (b) K. M. Brummond, H. Chen, K. D. Fisher, A. D. Kerekes, B. Rickards, P. C. Sill, S. J. Geib, ibid., 4, 1931 (2002)

15) J. L. Kent, H. Wan, K. M. Brummond, Tetrahedron Lett., 36, 2407 (1995)

16) (a) K. M. Brummond, H. Chen, P. Sill, L. You, J. Am. Chem. Soc., 124, 15186 (2002); (b) T. Shibata, Y. Takesue, S. Kadowaki, K. Takagi, Synlett, 2003, 268

17）門脇詳, 平瀬真也, 柴田高範, 高木謙太郎, 日本化学会第 83 春季年会， 3 G 4-12 (2003)

18) (a) T. Shibata, K. Yamashita, H. Ishida, K. Takagi, Org. Lett., 3, 1217 (2001); (b) T. Shibata, K. Yamashita, E. Katayama, K. Takagi, Tetrahedron, 58, 8661 (2002)

19) (a) T. Shibata, T. Ohta, K. Soai, Tetrahedron Lett., 39, 5785 (1998); (b) T. Shibata, K. Yamashita, K. Takagi, T. Ohta, K. Soai, Tetrahedron, 56, 9259 (2000)

20) W. Reppe, O. Schlichting, K. Klager, T. Toepel, Ann. Chem., 560, 1 (1948)

21) (a) H. Yamazaki, N. Hagihara, J. Organomet. Chem., 7, 22 (1967); (b) Y. Wakatsuki, T. Kuramitsu, H. Yamazaki, Tetrahedron Lett., 1974, 4549

22) Reviews: (a) K. P. C. Vollhardt, Acc. Chem. Res., 10, 1 (1977); (b) idem, Angew. Chem., 96, 525 (1984)

23) T. Shibata, T. Fujimoto, K. Yokota, K. Takagi, J. Am. Chem. Soc., 126, 8382 (2004)

24) Y. Sato, T. Nishimata, M. Mori, J. Org. Chem., 59, 6133 (1994)

25) I. G. Stará, I. Starý, A. Kollárovič, F. Teplý, Š. Vyskočil, D. Šaman, Tetrahedron Lett., 40, 1993 (1999)

26）筆者の研究とは独立に，コバルトならびにロジウム錯体によ
り，不斉 $[2+2+2]$ 付加環化反応による軸不斉化合物の触媒的 合成反応が報告された：(a) A. Gutnov，B. Heller, C. Fischer, H.-J. Drexler, A. Spannenberg, B. Sundermann, C. Sundermann, Angew. Chem. Int. Ed., 43, 3795 (2004); (b) K. Tanaka, G. Nishida, A. Wada, K. Noguchi, K. ibid., 43, 6510 (2004)

27）軸不斉化合物の合成に関する最近の総説：G. Bringmann, A. J. P. Mortimer, P. A. Keller, M. J. Gresser, J. Garner, M. Breuning, Angew. Chem. Int. Ed., 44, 5384 (2005)

28) T. Shibata, K. Tsuchikama, Chem. Commun., 2005, 6017

29）土釜恭直，柴田高範，日本化学会第 86 春季年会，4 H 1-29 (2006)

30) T. Shibata, K. Tsuchikama, M. Otsuka, Tetrahedron: Asymmetry, 17, 614 (2006)

31) T. Shibata, Y. Arai, Y. Tahara, Org. Lett., 7, 4955 (2005)

32) P. A. Evans, K. W. Lai, J. R. Sawyer, J. Am. Chem. Soc., 127, 12466 (2005)

33) T. Shibata, K. Takami, A. Kawachi, Org. Lett., 8, 1343 (2006)

34) (a) K. Villeneuve, R. W. Jordan, W. Tam, Synlett, 2003, 2123; (b) K. Villeneuve, W. Tam, Angew. Chem. Int. Ed., 43, 610 (2004)

35) (a) K. Narasaka, Y. Hayashi, H. Shimadzu, S. Niihata, J. Am. Chem. Soc., 114, 8869 (1992); (b) H. Ito, M. Hasegawa, Y. Takenaka, T. Kobayashi, K. Iguchi, ibid., 126, 4520 (2004)

36) T. Shibata, K. Takasaku, Y. Takesue, N. Hirata, K. Takagi, Synlett, 2002, 1681

37) T. Shibata, M. Yamasaki, S. Kadowaki, K. Takagi, Synlett, 2004, 2812

38) T. Shibata, Y. Kobayashi, S. Maekawa, N. Toshida, K. Takagi, Tetrahedron, 61, 9018 (2005)

\section{PROFILE}

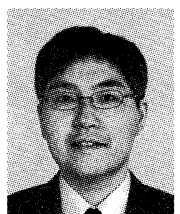

柴田高範 早稲田大学理工学術院化学科・教 授 博士 (理学)

〔経歴〕1994 年東京大学大学院理学系研究科 博士課程修了, 同年北里大学理学部助手, 1995 年東京理科大学理学部助手, 1999 年岡 山大学理学部助教授, 2003 年早稲田大学理 工学部助教授，2006 年より同教授。2001 年 ハーバード大学博士研究員 (E.J.Corey 教 授)。2005 年有機合成化学協会奨励賞。〔専 P門]有機合成化学, 有機金属化学。〔連絡先〕 e-mail: 